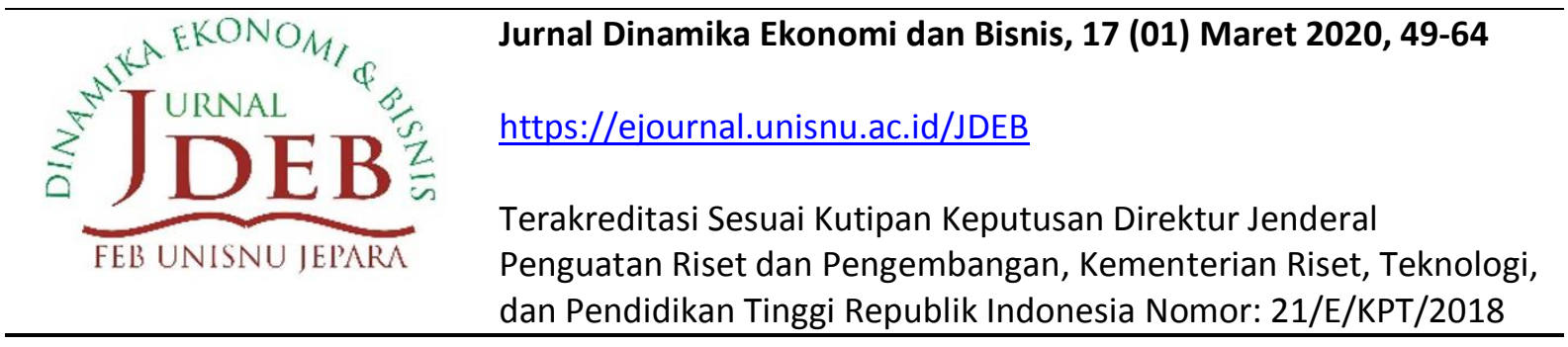

\title{
PRINSIP-PRINSIP JUAL BELI ONLINE DALAM ISLAM DAN PENERAPANNYA PADA E-COMMERCE ISLAM DI INDONESIA
}

\author{
Misbahul Ulum \\ Sekolah Pascasarjana Universitas Islam Negeri Syarif Hidayatullah Jakarta \\ Email: mis.ulum@gmail.com
}

\begin{abstract}
E-Commerce in Indonesia has moved very rapid development. Many e-commerce sites have begun to appear along with the development of information technology and internet penetration in the people. This development also took place in the Muslim market sector which was marked by the emergence of several Islamic e-Commerce. The emergence of Islamic e-Commerce is very understandable given the potential for transactions in the Muslim market in Indonesia is very large, reaching 2,800 trillion in 2012. This study aims to determine the extent to which the principles of online transaction in Islam are implemented on Islamic eCommerce sites in Indonesia, and to find out how to apply the principles of transaction in Islam to the practice of transactions through Islamic e-Commerce. This research is a qualitative research with an analytical descriptive approach. Data collection techniques are done through direct observation and documentation. Through research it is hoped that the practice of online transaction that takes place on Islamic e-Commerce sites is truly carried out in accordance with the principles of transaction in Islam.
\end{abstract}

Keywords: E-Commerce, Online Transaction, Principle of Transaction

\begin{abstract}
Abstrak
E-Commerce di Indonesia telah mengalami perkembangan yang sangat cepat. Banyak situs eCommerce yang mulai bermunculan seiring dengan perkembangan teknologi informasi dan penetrasi internet di masyarakat. Perkembangan tersebut juga terjadi pada sektor pasar Muslim yang ditandai dengan munculnya beberapa e-Commerce Islam. Kemunculan e-Commerce Islam ini sangat bisa dimaklumi mengingat potensi transaksi pada pasar Muslim di Indonesia sangat besar, yakni mencapai 2.800 triliun pada tahun 2012. Penelitian ini bertujuan untuk mengetahui sejauh mana prinsip-prinsip jual beli online dalam Islam terimplementasi pada situs e-Commerce Islam di Indonesia, serta untuk mengetahui bagaimana bentuk penerapan prinsip-prinsip jual beli dalam Islam pada praktik transaksi melalui e-Commerce Islam. Penelitian ini adalah penelitian kualitatif dengan pendekatan deskriptif analitis. Teknik pengumpulan data dilakukan melalui observasi langsung dan dokumentasi. Melalui penelitian diharapkan agar praktik jual beli online yang terjadi pada situs e-Commerce Islam benar-benar dijalankan sesuai dengan prinsip-prinsip jual beli dalam Islam.
\end{abstract}

Kata Kunci: E-Commerce Jual Beli Online, Prinsip Jual Beli.

Sitasi: Ulum, M. (2020). Prinsip-prinsip Jual Beli Online dalam Islam dan Penerapannya pada e-Commerce Islam di Indonesia, Jurnal Dinamika Ekonomi dan Bisnis, 17 (01) 2020, 49-64. 


\section{PENDAHULUAN}

Transaksi jual beli sesungguhnya memiliki posisi yang sangat penting dalam kehidupan umat manusia. Jual beli menjadi sarana manusia untuk saling memenuhi kebutuhan satu sama lain. Keberadaan kegiatan jual beli juga sekaligus menjadi bukti bahwa manusia adalah makhluk sosial yang dalam pemenuhan kebutuhan hidupnya membutuhkan keterlibatan manusia lain (Nurhayati, 2015).

Melalui transaksi jual beli seseorang dapat memperoleh barang-barang yang dibutuhkan untuk menunjang kehidupannya secara lebih mudah dan efisien. Tidak hanya itu, melalui transaksi jual beli ini pula, seseorang mampu mendapatkan keuntungan atau nilai lebih guna meningkatkan taraf dan kualitas hidup. Sebab pada dasarnya jual beli adalah proses perolehan keuntungan yang didasarkan atas supply dan demand, yakni pembeli memperoleh manfaat untuk menggunakan suatu produk dengan membayar harga tertentu, sementara penjual memperoleh keuntungan dari harga jual produk yang diinginkan pembeli (Sulaiman, 2010).

Dalam pandangan Islam, jual beli menjadi salah satu diskursus yang mendapatkan perhatian secara serius. Islam memberikan ketentuan yang cukup ketat dalam praktik perniagaan atau jual beli. Dalam pelaksanaan kegiatan jual beli, Islam sangat mengedepankan prinsip saling rela (ridha) dan juga menghindari riba, sebagaimana firman Allah dalam QS alBaqarah ayat 275. Al-Qur'an sebagai sumber hukum Islam telah mengatur secara eksplisit mengenai pokok-pokok kegiatan jual beli. Al-Qur'an sangat mendorong dan memberikan motivasi kepada umat Islam untuk melakukan perniagaan dalam kehidupan mereka. Di saat yang sama, al-Qur'an juga memberikan pengakuan dan legitimasi atas kegiatan perniagaan serta memberikan kaidah-kaidah dasar yang dapat dijadikan sebagai rujukan dalam kegiatan jual beli tersebut. Beberapa di antaranya adalah al-Qur'an mengakui hak individu dan hak kelompok untuk memiliki kekayaan tanpa paksaan, al-Qur'an mengakui otoritas delegative harta yang dimiliki secara legal oleh individu maupun kelompok, al-Qur'an memberikan kemerdekaan penuh untuk melakukan transaksi apa saja sesuai dengan batas-batas yang ditentukan oleh syariat, serta al-Quran memandang bahwa kekayaan adalah sesuatu yang tidak bisa diganggu gugat dan tindakan penggunaan harta orang lain melalui cara yang tidak halal tanpa izin pemilik yang sah merupakan perbuatan yang dilarang (Rivai, 2011).

Dewasa ini, praktik jual beli mengalami perkembangan dan perubahan yang cukup signifikan sejalan dengan perkembangan teknologi informasi yang telah mengubah hampir seluruh kehidupan manusia. Perkembangan teknologi informasi yang berlangsung sangat pesat, akhirnya memberikan pengaruh besar dalam kehidupan ummat manusia. Kecanggihan teknologi modern dan keterbukaan jaringan informasi global yang semakin transparan telah membawa manusia ke dalam suatu peradaban yang oleh Toffler disebut sebagai gejala masyarakat gelombang ketiga (Dharma, 2016). Gelombang masyarakat ketiga ini ditandai dengan munculnya internet yang memungkinkan adanya transformasi secara cepat ke seluruh jaringan dunia melalui dunia maya. Dengan teknologi internet inilah, perilaku manusia (human action), interaksi antar manusia (human interaction), serta hubungan kemanusiaan (human relation) mengalami perubahan yang sangat signifikan. Jaringan komunikasi global yang semakin canggih akhirnya menciptakan tantangan-tantangan baru terhadap tata cara pengaturan transaksi-transaksi sosial maupun transaksi ekonomi (Husaini, 2014). 
Kemunculan situs-situs perdagangan online atau yang lazim disebut e-commerce seperti Amazon, Alibaba, e-Bay, dan sederet nama e-commerce besar lainnya semakin menunjukkan bahwa keterlibatan internet dalam transaksi ekonomi adalah suatu keniscayaan. Bahkan, dalam perkembangan terbaru, khususnya di Indonesia, nama-nama perusahaan retail besar seperti Matahari Mall telah merambah dunia online sebagai bentuk perluasan bisnis dengan mendirikan situs mataharimall.com. Tidak hanya itu, beberapa layanan keuangan di Indonesia juga mulai melirik pasar internet sebagai upaya untuk memperbesar dan memperluas usaha yang mereka lakukan (Tech in Asia, 2014).

Seiring perjalanan waktu, situs e-commerce yang bercorak Islam perlahan mulai bermunculan. Situs-situs e-commerce tersebut menjadi pendatang baru dalam dinamika persaingan antar situs e-commerce besar yang sudah lebih dulu ada di Indonesia. E-commerce yang bercorak Islam tersebut muncul dengan kekhasan masing-masing. Paling tidak terdapat tiga kategori e-commerce yang bercorak Islam. Pertama, e-commerce yang mengidentifikasi diri sebagai e-commerce Islam dengan menjadikan umat Islam sebagai target dan market utama mereka seperti situs Hijup.com, Saqina.com, dan Hijabenka.com. Kedua, e-commerce yang memberikan layanan jasa seputar kegiatan-kegiatan Islam, seperti Ibadah haji, umrah, serta ritual Islam lainnya seperti situs Ihram.asia. Ketiga, e-commerce yang menjadikan identitas Islam sebagai bagian dari nama usaha yang dijalankan seperti situs muslimarket.com.

Dari beberapa uraian di atas terlihat bahwa kehadiran e-commerce yang bercorak Islam di Indonesia sesungguhnya adalah sebuah fenomena yang tidak bisa dipandang sebelah mata. Potensi besar umat Islam ditambah dengan perkembangan teknologi informasi yang kian pesat adalah modal yang sangat kuat untuk menciptakan ekosistem baru perekonomian umat Islam yang lebih kuat melalui jalur teknologi informasi.

Oleh karena itulah, kehadiran e-commerce yang dikelola berdasarkan prinsip-prinsip Islam mutlak diperlukan. Terlebih lagi, situs-situs e-commerce yang bercorak Islam sudah mulai berkembang dan semakin menunjukkan eksistensi masing-masing. Kesadaran masyarakat Muslim di Indonesia dalam memanfaatkan perkembangan teknologi juga telah mengalami peningkatan yang cukup pesat. Penelitian Lembaga Konsultan In-venture menunjukkan bahwa konsumen Muslim di Indonesia saat ini semakin memiliki pengalaman yang luas dan juga semakin sadar dan melek teknologi atau technology-savvy (Tech in Asia, 2014). Untuk itulah, situs-situs e-commerce yang bercorak Islam tentunya harus dikelola berdasarkan prinsip-prinsip Islam, bukan hanya sekedar menjadikan Islam dan masyarakat Muslim sebagai komoditas ekonomi yang dapat dikapitalisasi semata. E-commerce Islam harus mampu memberikan solusi kegiatan jual beli yang tidak merugikan orang lain, serta mampu berjalan menuju perekonomian yang sehat (Siddik, 1993).

Lebih jauh, kehadiran e-commerce yang aman, ramah, dan nyaman sangat dibutuhkan masyarakat. Hal ini terlihat dari fakta bahwa masih banyak tindakan penipuan yang dilakukan melalui dunia maya, termasuk layanan e-commerce. Kaspersky Lab sebagaimana dikutip oleh Beritasatu.com merilis bahwa Indonesia menjadi negara yang masuk dalam tiga besar negara dengan kasus penipuan online tertinggi, yakni dengan tingkat penipuan online sebesar $26 \%$, kemudian disusul Vietnam 25\%, dan India 24\% (Berita Satu, 2016). Untuk itulah, Indonesia 
sebagai negara dengan mayoritas Muslim perlu mendorong upaya pengaturan e-commerce yang lebih Islami, atau paling tidak yang menjadikan prinsip-prinsip Islam sebagai panduan. Sebab apabila bisnis dijalankan dengan aturan syariah secara kaffah (menyeluruh dan terpadu), secara otomatis hal-hal seperti Good Corporate Governance, Corporate Social Responsibility, Good Business Ethics, Quality Assurance (Amanah), Continuing Improvement (Kaizen), Eco-Friendly yang selama ini didengung-dengungkan sebagai bagian dari upaya menciptakan keseimbangan dan kesinambungan suatu bisnis, akan tercipta dengan sendirinya (Sofyan, 2011).

\section{TELAAH PUSTAKA}

\section{Prinsip-Prinsip Jual Beli dalam Islam}

Dalam kaidah bahasa Arab, istilah jual beli secara umum dikenal dengan nama al-bay' yang merupakan bentuk isim mashdar dari fi'il madli باع yang bermakna menjual. Sementara itu, kata membeli sebenarnya memiliki kosa kata tersendiri yaitu kata syara-a yang merupakan bentuk isim mashdar dari fi'il madli شرى (Munawir, 1997). Namun walaupun demikian, kata البيع Sesungguhnya merupakan kata yang telah mencakup kedua makna tersebut, yaitu mengandung makna menjual dan membeli, atau dengan kata lain, kata al-bay' selain bermakna menjual juga bermakna membeli sekaligus (Abdullah, 2011). Sementara itu menurut As-Sayyid Sabiq definisi jual beli adalah melepaskan harta dengan mendapatkan harta lain berdasarkan kerelaan atau memindahkan milik dengan mendapatkan benda lain sebagai ganti secara suka rela dan tidak bertentangan dengan syara' (Sabiq, 1883).

Berkaitan dengan prinsip-prinsip jual beli dalam Islam, sampai saat ini belum ada literatur yang secara khusus memberikan pembahasan secara tegas dan rinci. sekalipun ada, pembahasan mengenai prinsip jual beli tersebut masih bersifat parsial dan terbatas pada prinsip-prinsip ekonomi Islam. Untuk itulah, penulis berusaha merangkum untuk kemudian merumuskan prinsip jual beli berdasarkan literatur dan rujukan ke dalam satu rumusan tersendiri. Prinsip-prinsip jual beli tersebut di antaranya adalah prinsip tauhid, prinsip akhlak, prinsip keseimbangan, prinsip kebebasan individu, prinsip keadilan, dan prinsip sahih (jual beli dilakukan dengan memenuhi syarat dan rukun jual beli). Adapun uraian dari masingmasing prinsip tersebut adalah sebagai berikut:

1. Prinsip Ketuhanan (Tauhid)

Prinsip ini menuntut kesadaran bahwa semua adalah milik Allah dan semua aktivitas diawasi oleh Allah. Selain itu, transaksi jual beli tidak semata dilakukan dalam rangka mencari keuntungan dunia (Mardani, 2015). Tetapi lebih dari itu bahwa keuntungan dalam kegiatan jual beli adalah bekal dalam menyongsong kehidupan di akhirat nanti. Implementasi prinsip ketuhanan adalah terwujudnya seorang pengusaha Muslim yang menghindari segala bentuk eksploitasi, serta menghindari transaksi yang mengandung unsur riba.

2. Prinsip Kerelaan (saling rela/ Ridhaiyyah).

Dalam praktik jual beli, prinsip saling rela ditandai dengan adanya akad ijab dan qabul yang dilakukan tanpa paksaan serta bebas dari berbagai intimidasi, penipuan, dan penyamaran (Hidayat, 1998). Secara lebih teknis, implementasi prinsip ini adalah 
masing-masing pihak berkewajiban memberikan informasi yang lengkap dan benar agar tidak terjadi asymmetric information, yaitu suatu kondisi di mana salah satu pihak tidak memiliki informasi yang lengkap dan baik dari pada pihak yang lain (World Bank, 2003). Keberadaan informasi yang lengkap dan benar itu menjadi faktor penting untuk menjadi pertimbangan dalam transaksi. Informasi-informasi yang dimaksud setidaknya meliputi; kualitas, kuantitas, harga, serta waktu penyerahan. Apabila hal tersebut tidak terpenuhi maka akan terjadi tadlis atau penipuan (Karim, 2004).

3. Prinsip Kemanfaatan atau Kemaslahatan.

Kegiatan jual beli harus bisa memberikan kemanfaatan bagi pihak-pihak yang bertransaksi. Kemanfaatan tersebut dapat berupa manfaat yang diperoleh dari objek atau barang yang diperjualbelikan, maupun manfaat dari hasil kegiatan jual beli yang dilakukan. Yakni, objek atau barang yang ditransaksikan harus memberikan manfaat bagi kemanusiaan, bukan justru membawa dampak kerusakan (Mardani, 2015).

4. Prinsip Keadilan

Prinsip keadilan dalam transaksi jual beli dapat dilakukan dengan sikap tidak saling mezalimi. Penjual harus mampu bersikap adil kepada seluruh pembeli, demikian halnya sebaliknya (Syaltut, 1990). Selain itu, termasuk juga bagian dari prinsip keadilan adalah menetapkan harga secara wajar, serta tidak melakukan praktik monopoli (Rozalinda, 2014).

5. Prinsip Kejujuran

Penerapan prinsip kejujuran dalam transaksi jual beli dapat dilakukan dengan memberikan informasi secara objektif, benar, apa adanya, dan menyeluruh. Konsekuensi dari prinsip kejujuran ini adalah larangan terhadap segala bentuk tindakan penipuan, baik penipuan dalam bentuk perkataan maupun perbuatan. Prinsip kejujuran ini ditegaskan oleh Allah dalam QS al-Muthaffifin ayat 1-3 yang memberikan ancaman kepada seseorang yang tidak jujur dalam melakukan takaran timbangan (Mursal, 2015).

6. Prinsip Kebebasan

Yaitu prinsip untuk menentukan suatu tindakan atau suatu keputusan sepanjang tidak bertentangan dengan kerangka syariat Islam (Rivai, 2009). Pelaksanaan prinsip kebebasan dalam kegiatan jual beli adalah adanya hak dan kesempatan untuk memilih atau yang lazim disebut dengan istilah khiyar. Dalam konteks jual beli, khiyar adalah suatu keadaan yang menyebabkan 'aqid (orang yang berakad) memiliki hak untuk memutuskan akadnya, yakni menjadikan atau membatalkannya. Salah satu tujuan khiyar adalah untuk menjamin agar akad yang dilaksanakan benar-benar terjadi atas kerelaan penuh antara para pihak yang berakad (Azhar, 2000).

7. Prinsip Akhlak/ Etika

Prinsip ini merupakan bentuk dari pengamalan sifat-sifat utama nabi dan rasul dalam seluruh kegiatan ekonomi, yaitu sidiq (benar), amanah (dapat dipercaya), tabligh (menyampaikan kebenaran), dan fathanah (cerdas/ berilmu). Akhlak adalah urat nadi kehidupan Islami, termasuk dalam kehidupan ekonomi. Seorang Muslim tidak dibenarkan untuk bebas melakukan apa saja yang diinginkannya atau apa saja yang menguntungkannya dalam kegiatan usaha dan mengembangkan hartanya (Qardhawi, 
2004). Secara umum prinsip akhlak atau etika dalam transaksi mencakup segala perilaku yang baik dan tidak merugikan siapapun, seperti bersikap jujur, tidak bersumpah palsu, tidak melakukan perjudian, serta dapat dipercaya.

\section{Prinsip Sahih}

Suatu kegiatan jual beli dinilai sebagai jual beli yang sahih apabila syarat dan rukun jual beli terpenuhi dengan baik dan benar. Sehingga, implementasi prinsip sahih dalam kegiatan jual beli dapat dilihat dari terpenuhinya syarat-syarat dan rukun jual beli yang meliputi:

a. Pihak yang berakad harus memenuhi kriteria sebagai berikut:

1) Mumayyiz, yaitu dapat membedakan antara yang baik dan buruk (Jawad, 2011)

2) Baligh, yaitu masa di mana seseorang dapat dibebani hukum secara syar'i, sehingga apabila ia melakukan transaksi, ia mengerti tentang konsekuensi hukum atas transaksi yang ia lakukan serta secara sah dapat dimintai pertanggungjawaban atas apa yang ia lakukan (Hadrawi, 2012).

3) Tidak dalam paksaan

4) Bukan orang yang mubadhir, yakni pembeli dan penjual bukanlah orang yang berperilaku boros. Sebab perilaku boros adalah indikator bahwa seseorang tersebut tidak cakap dalam bertindak (Basaribu, 1996). Selain itu, pengelolaan harta orang yang boros berada di dalam kekuasaan walinya, bukan berada di dalam kekuasaannya sendiri (Rasyid, 1954).

b. Objek akad harus memenuhi kriteria sebagai berikut:

1) Ada dan nyata, yakni barang yang diperjualbelikan harus benar-benar nyata dan ada. Sekalipun barang tersebut tidak ada di tempat, penjual harus menyatakan kesanggupannya untuk mengadakan atau menghadirkan barang tersebut. Oleh karena itulah, tidak boleh ada akad jual beli terhadap barang yang tidak ada atau dikhawatirkan tidak ada (Rahman, 2010).

2) Suci, yakni barang yang dijadikan sebagai objek jual beli bukan barang yang najis atau barang yang diharamkan menurut syariat Islam.

3) Bermanfaat, yakni objek jual beli harus hal yang memberikan manfaat, bukan justru memberikan madlarat.

4) Milik sendiri, yakni barang yang dijadikan sebagai objek akad haruslah barang milik sendiri atau setidaknya yang bersangkutan memiliki hak kuasa atas barang tersebut. Seseorang dianggap sebagai pemilik apabila penjualan benda tersebut telah diizinkan oleh pemiliknya yang sah (As-Sabatin, 2014).

5) Dapat diserahterimakan, yakni barang yang dijadikan sebagai objek akad harus dapat diserahterimakan waktu akad terjadi. Dalam hal ini para imam mazhab sepakat bahwa jual beli terhadap barang yang tidak bisa diserahterimakan adalah tidak sah, karena mengandung unsur gharar. Praktik jual beli dengan objek yang tidak dapat diserahterimakan disebut juga dengan ba'i ma'juz al-Taslim (Samad, 2016).

c. Akad ijab dan qabul harus sesuai dan dilaksanakan dalam satu transaksi. Pelaksanaan ijab dan qabul dapat dilakukan dengan beberapa cara. Pertama dengan lisan, yakni 
menggunakan bahasa atau perkataan yang dimengerti oleh masing-masing pihak yang bertransaksi. Kedua dengan tulisan, yakni dilakukan secara tertulis oleh salah satu pihak atau keduanya. Ketiga dengan isyarat, yaitu dengan bahasa isyarat yang dimengerti oleh masing-masing pihak yang berakad (Bhinadi, 2018).

d. Harga atau nilai tukar harus disepakati oleh masing-masing pihak dan dibayarkan pada saat transaksi, apabila pembayaran dilakukan ditangguhkan (utang) maka waktu pelunasan harus ditentukan dengan jelas.

Untuk memudahkan pemetaan terhadap prinsip-prinsip jual beli dalam Islam berikut ini penulis sederhanakan dalam bentuk tabel berikut dengan indikator dari prinsip-prinsip tersebut.

Tabel 1. Prinsip-prinsip Jual Beli dalam Islam

\begin{tabular}{|c|c|c|}
\hline No & Prinsip & Indikator \\
\hline 1. & Kerelaan & - Adanya akad Ijab dan Qabul. \\
\hline 2. & Kemanfaatan & - Objek dan subjek transaksi bermanfaat secara fungsional. \\
\hline 3. & Keadilan & $\begin{array}{l}\text { - Keadilan kepada seluruh pembeli (tidak membeda-bedakan) } \\
\text { - Penetapan harga dan keuntungan secara wajar. } \\
\text { - } \quad \text { Tidak melakukan praktik monopoli }\end{array}$ \\
\hline 4. & Ketuhanan & $\begin{array}{l}\text { - Tidak melakukan eksploitasi } \\
\text { - Tidak melakukan riba }\end{array}$ \\
\hline 5. & Kejujuran & $\begin{array}{l}\text { - Adanya informasi yang benar dan lengkap tentang kualitas, harga, } \\
\text { dan waktu penyerahan barang. } \\
\text { - Tidak melakukan penipuan. }\end{array}$ \\
\hline 6. & Kebebasan & - Adanya khiyar \\
\hline 7. & Akhlak / Etika & - Melakukan kebaikan dan menghindari keburukan dalam transaksi. \\
\hline 8. & Sahih & $\begin{array}{l}\text { - Syarat rukunnya terpenuhi } \\
\text { a. Pihak yang berakad (Penjual dan Pembeli) } \\
\text { 1. Mumayyiz } \\
\text { 2. Baligh } \\
\text { 3. Tanpa Paksaan } \\
\text { 4. Bukan orang yang mubadzir } \\
\text { b. Objek Akad } \\
\text { 1. Objek nyata dan ada } \\
\text { 2. Objek Suci } \\
\text { 3. Bermanfaat } \\
\text { 4. Milik Sendiri } \\
\text { 5. Dapat diserahterimakan } \\
\text { c. Sighat ijab dan qabul } \\
\text { 1. Qabul sesuai Ijab } \\
\text { 2. Ijab dan qabul dilakukan dalam satu transaksi } \\
\text { d. Harga atau nilai tukar } \\
\text { 1. Disepakati oleh masing-masing pihak } \\
\text { 2. Dibayarkan pada saat transaksi, jika utang, waktu } \\
\text { pelunasan harus ditentukan dengan jelas. }\end{array}$ \\
\hline
\end{tabular}




\section{Diskursus E-Commerce Islam}

Istilah e-commerce yang selama ini digunakan untuk menyebut perdagangan elektronik atau perdagangan online, sesungguhnya terbentuk dari dua kata yang berbeda, yaitu kata electronic (kemudian disingkat dengan huruf "e") yang bermakna segala hal yang berhubungan dengan elektronika dan teknologi, dan kata Commerce yang bermakna perdagangan atau perniagaan (Safrudin, 2015). Apabila dua makna kata ini digabung, maka $e$ commerce dapat dimaknai sebagai perdagangan melalui perantara teknologi.

Menurut Qin (2009) mendefinisikan bahwa e-commerce adalah berbagai aktivitas komersial yang bersifat online yang berfokus pada pertukaran komoditas secara elektronik, baik dilakukan oleh perusahaan, pabrik, industri, dan perusahaan komersial lainnya, dengan memanfaatkan komputer dan jaringan internet (Qin, 2009).

Berkaitan dengan e-commerce Islam, sesungguhnya, secara teoritis tidak ada pembahasan khusus mengenai keberadaan e-commerce Islam atau perdagangan online syariah, karena perdagangan online di internet pada dasarnya adalah sebuah ruang bebas yang muncul atas semangat efisiensi dan semangat tanpa sekat. Namun, secara faktual banyak pelaku bisnis e-commerce yang bergerak di bidang gaya hidup halal (halal life style) dengan berbagai model bisnis. Kemunculan berbagai e-commerce tersebut akhirnya dimaknai sebagai kemunculan "e-commerce Islam" yang turut memberikan warna dalam dunia "Islamic Digital" yang saat ini sedang berkembang cukup pesat (DTEC, 2017). Bahkan, dalam rangka memperkuat dan mengoptimalkan ekosistem "Islamic Digital", telah dibangun berbagai inkubator Islamic Digital di berbagai negara yang bertujuan untuk mengembangkan bisnis Islami, misalnya Malaysia memiliki Malaysia Tech Entrepreneur Pass (MTEP) (Medium, 2017) serta Dubai memiliki Dubai Technology Entrepreneur Centre (DTEC).

Di Indonesia, perkembangan bisnis digital yang ditandai dengan hadirnya berbagai Start-up, akhirnya menjadi inspirasi lahirnya bisnis digital dengan pendekatan Islami. Momentum perkembangan usaha berbasis syariah ditopang dengan perkembangan teknologi yang semakin canggih, akhirnya memicu lahirnya bisnis syariah di dunia digital. Bahkan, beberapa lembaga dan organisasi kemasyarakatan Islam juga mulai mengembangkan usaha di dunia online. Lembaga Dakwah Islam Indonesia (LDII) misalnya, pada pelaksanaan musyawarah Nasional ke VIII, resmi meluncurkan program untuk mengatasi permasalahan ekonomi umat. Program tersebut salah satunya adalah dengan mendirikan e-commerce Syariah dengan nama pikub.com (Online24Jam.com, 2016).

Selain itu, ormas keagamaan Islam terbesar di Indonesia, yakni Nahdlatul Ulama' dan Muhammadiyah juga telah mulai menjalankan usaha di dunia digital. Muhammadiyah membangun situs toko online Muhammadiyahstore.com yang menjual beraneka ragam buku serta majalah seputar Muhammadiyah, sementara Nahdlatul Ulama' melalui situs toko.nu.or.id menjual beraneka ragam produk, mulai dari buku, busana Muslim, hingga obatobatan herbal syariah.

Berdasarkan uraian serta data-data yang telah diurai sebelumnya semakin terlihat jelas bahwa perkembangan usaha Islamic digital di Indonesia telah menjadi model bisnis tersendiri. Potensi dan peluang perkembangannya masih sangat terbuka lebar, terlebih di tengah 
kesadaran masyarakat Muslim di Indonesia tentang pentingnya menghadirkan nilai-nilai syariah dalam kehidupan sudah mulai tumbuh.

\section{METODE PENELITIAN}

Penelitian ini adalah penelitian deskriptif - kualitatif, yakni penelitian yang berusaha memberikan gambaran dan menginterpretasikan sebuah objek sesuai dengan realitas aslinya serta memberikan gambaran secara sistematis berkaitan dengan fakta-fakta dan karakteristik objek yang diteliti secara tepat (Sukardi, 2008). Sumber data primer dalam penelitian ini adalah hasil observasi langsung ke dalam objek penelitian yaitu e-commerce Hijup.com. Sementara itu, sumber data sekunder diperoleh dari buku dan literatur tertulis lainnya yang menunjang penelitian ini. Objek penelitian ini adalah e-commerce Hijup.com yaitu sebuah $e$ commerce terbesar di Indonesia untuk kategori Muslim style versi Tech in Asia. Penelitian ini menggunakan teknik analisis yang dikembangkan oleh Miles dan Huberman (Sugiyono, 2009), yaitu melalui tahapan reduksi data (data reduction), penyajian data (data display), hingga penarikan kesimpulan atau verifikasi (conclusion drawing/verification).

\section{HASIL DAN PEMBAHASAN}

\section{Praktik Transaksi Jual Beli pada e-Commerce Hijup.com}

Pada pembahasan ini, penulis akan menguraikan alur dan proses jual beli dalam $e$ commerce Hijup.com. Selain itu, penulis juga akan mengurai beberapa ketentuan yang ditetapkan oleh Hijup.com dan berlaku dalam kegiatan jual beli tersebut. Secara umum, kegiatan jual beli melalui situs e-commerce Hijup.com berjalan dengan tahapan sebagai berikut:

1. Pembeli melakukan registrasi dan Sig in

Untuk melakukan transaksi di situs Hijup.com, calon pembeli harus terlebih dahulu login ke situs Hijup.com dengan memasukkan e-mail sebagai username dan password. Namun, bagi calon pembeli yang baru pertama kali mengakses situs Hijup.com, calon pembeli harus melakukan registrasi (pendaftaran) terlebih dahulu untuk mendapatkan hak akses masuk ke situs e-commerce Hijup.com ini.

Dalam melakukan pendaftaran, calon pembeli harus melakukan pengisian formulir yang di dalamnya memuat data dan informasi tentang alamat $e$-mail, nama calon pembeli, No Handphone yang masih aktif, serta alamat calon pembeli (alamat inilah nantinya digunakan oleh Hijup.com sebagai alamat tujuan pengiriman barang ketika terjadi pembelian).

2. Memilih produk

Tahap berikutnya calon pembeli dapat mencari, memilih serta memilah produk yang diinginkan sesuai dengan ketersediaan produk yang terdapat dalam situs Hijup.com. Dalam proses pemilihan produk, situs Hijup.com menerapkan beberapa ketentuan yang perlu diperhatikan oleh calon pembeli (Hijup.com, 2017):

a. Apabila suatu produk tertulis "Sold Out" berarti produk tersebut tidak tersedia atau stock produk tersebut habis. 
b. Untuk memastikan ukuran produk, situs Hijup.com telah menyediakan panduan ukuran agar produk yang dipilih benar-benar sesuai dengan ukuran tubuh calon pembeli.

c. Hijup.com menyediakan panduan perawatan agar produk yang dibeli tidak cepat rusak dan tetap terawat. Panduan tersebut meliputi jenis bahan yang digunakan serta cara merawat bahan secara baik dan benar.

3. Melakukan pembelian

Setelah calon pembeli menemukan produk yang cocok dan sesuai serta telah yakin untuk membelinya, pembeli harus memastikan keinginan pembeliannya dengan melakukan klik tombol "beli sekarang" atau "tambah ke wish list". Apabila calon pembeli meng-klik tombol "beli sekarang", maka produk yang diinginkan akan langsung ditambahkan ke dalam "tas belanja" dan siap untuk dibayar. Namun, apabila calon pembeli menekan tombol "wish list", maka produk yang diinginkan akan langsung tersimpan dalam list produk yang mau dibeli tanpa ada perintah untuk melakukan pembayaran.

4. Melakukan pembayaran dan konfirmasi.

Tahap selanjutnya, untuk melanjutkan proses pembelian, calon pembeli harus melakukan pembayaran sesuai dengan jumlah nominal tertentu yang terdapat dalam tagihan, yang terdiri atas harga barang ditambah dengan ongkos kirim. Jika sampai dengan waktu 1 x 12 jam sejak pemesanan dilakukan tetapi pembeli tidak melakukan proses pembayaran dan konfirmasi pembayaran, maka pesanan akan dibatalkan secara otomatis oleh sistem Hijup.com.

Namun, apabila calon pembeli telah melakukan pembayaran dan konfirmasi pembayaran, Hijup.com akan menindaklanjuti dan memproses pembayaran tersebut paling lama 2 jam setelah konfirmasi dilakukan. Limitasi waktu inilah yang membuat proses jual beli di Hijup.com memenuhi prinsip kepastian.

Untuk memudahkan proses pembayaran, Hijup.com memiliki beberapa metode pembayaran yang dapat dipilih oleh pembeli, yaitu pembayaran dengan metode transfer langsung ke rekening Hijup.com, pembayaran dengan kartu kredit, PayPal, Hijup Point, dan juga pembayaran dengan metode COD (Cash On Delivery) atau bayar di tempat. Namun, metode COD hanya tersedia untuk daerah tertentu saja seperti Jabodetabek (Jakarta, Bogor, Depok, Tangerang dan Bekasi), Medan, Bandung, dan Surabaya, dengan estimasi waktu pengiriman selama 2-3 hari.

5. Pengiriman Produk kepada Pembeli

Setelah pembeli benar-benar melakukan pembayaran, produk yang dipesan akan dikirim oleh Hijup.com kepada pembeli sesuai dengan alamat yang terdaftar. Untuk pelaksanaan pengiriman Hijup.com menggunakan jasa ekspedisi pihak ketiga seperti JNE, Ninja Ekspress, dan Grab. Atas penggunaan jasa pengiriman inilah dikenakan biaya pengiriman sesuai dengan tarif masing-masing perusahaan jasa pengiriman, yang pembayarannya dibebankan kepada pembeli dan telah dihitung bersama dengan harga barang yang dibeli. 
6. Retur dan penukaran

Apabila produk yang diterima oleh pembeli terdapat cacat atau ketidaksesuaian antara barang yang diterima dengan barang yang dipesan, Hijup.com menyediakan fasilitas pengembalian barang (return) dan penukaran barang (exchange). Pengembalian barang dan penukaran dapat dilakukan apabila terdapat beberapa sebab sebagai berikut:

a. Ukuran barang yang diterima oleh pembeli tidak sesuai dengan ukuran yang telah dipesan.

b. Terdapat cacat pada barang yang diterima oleh pembeli.

c. Warna barang yang diterima oleh pembeli tidak sesuai dengan warna yang terdapat pada foto display produk yang telah dipesan.

Untuk dapat melakukan pengembalian maupun penukaran barang, pembeli harus melakukan konfirmasi penukaran produk terlebih dahulu yang dapat dilakukan maksimal 2 x 24 jam setelah produk diterima oleh pembeli. Sementara itu, untuk pengembalian barang kepada Hijup.com, dapat dilakukan dalam jangka waktu 7 x 24 jam sejak barang diterima melalui jasa pengiriman barang. Pembeli yang melakukan pengembalian harus menyertakan dokumen tanda penerimaan barang. Namun, khusus untuk produk yang masuk dalam kategori produk promo atau diskon yang dibeli dengan Hijup Poin tidak dapat ditukar atau dikembalikan. Namun demikian, layanan penukaran dan pengembalian tidak dapat digunakan apabila barang yang dikembalikan sudah dalam keadaan tidak original, yakni sudah pernah digunakan, diubah, dicuci, dan label/price tag sudah tidak ada.

Selain tahapan jual beli sebagai yang sudah diuraikan di atas, situs e-commerce Hijup.com memiliki beberapa ketentuan dan kebijakan lain, diantaranya yaitu:

a. Sebagai sebuah badan usaha, Hijup.com memiliki kebijakan perusahaan, salah satu kebijakannya adalah kebijakan privasi, yaitu Hijup.com akan menyimpan dan melindungi data dan informasi seluruh pelanggan serta tidak akan menggunakannya untuk kepentingan eksploitasi, sehingga data tersebut tidak akan dijual, disewa atau dibagikan kepada pihak lain.

b. Dalam proses kegiatan jual beli, Hijup.com menerapkan prinsip layanan First pay first served. Yaitu Hijup.com akan melayani terlebih dahulu orang-orang yang membayar lebih awal.

c. Sebagai bentuk ekspansi usaha dan untuk memudahkan akses situs Hijup.com melalui perangkat mobile, Hijup.com telah memiliki Aplikasi Hijup.com yang dapat diunduh secara gratis di Playstore dan AppStore.

d. Sebagai e-commerce yang memiliki pelanggan tidak hanya dari dalam negeri, Hijup.com menyediakan Fasilitas pengiriman internasional untuk pembeli yang berasal dari manca negara.

e. Selain Hijup.com memproduksi produk-produk mereka dengan menggandeng desainer Muslimah ternama Indonesia, Hijup.com juga membuka diri kepada produsen busana Muslim/ Muslimah (tenant) untuk memasarkan produknya melalui Hijup.com. hanya saja, untuk menjadi tenant harus memenuhi standar produk yang disyaratkan oleh Hijup.com. 
f. Situs e-commerce Hijup.com tersedia dalam beberapa bahasa, meliputi bahasa Indonesia, bahasa Inggris, bahasa Malaysia, dan bahasa Brunei Darussalam. Keragaman pilihan bahasa tersebut juga disertai dengan ragam pilihan mata uang masing-masing negara yang berbeda pula.

g. Situs e-commerce Hijup.com tidak melayani reseller. Seluruh produk yang dimiliki oleh Hijup.com serta tenant Hijup.com seluruhnya dijual melalui situs hijup.com dan Hijup.com adalah penjual akhir yang langsung penjual kepada pengguna.

\section{Penerapan Prinsip-prinsip Jual Beli pada Transaksi di $e$-Commerce Hijup.com}

Berdasarkan alur dan proses transaksi jual beli online pada situs e-commerce Hijup.com dapat dilihat bahwa prinsip-prinsip jual beli dalam Islam terimplementasi dalam beberapa bentuk sebagaimana tabel di bawah ini.

Tabel 2. Implementasi Prinsip-prinsip Jual Beli dalam Islam pada Transaksi e-commerce Hijup.com

\begin{tabular}{|c|c|c|c|}
\hline No & Prinsip & Indikator & Implementasi \\
\hline 1. & Kerelaan & $\begin{array}{l}\text { - Adanya akad Ijab dan } \\
\text { Qabul }\end{array}$ & $\begin{array}{l}\text { - Ijab ditandai dengan uraian pembelian } \\
\text { dalam halaman "tas belanja" } \\
\text { - Qabul ditandai dengan kesediaan pembeli } \\
\text { melakukan konfirmasi pembelian sesuai } \\
\text { dengan ringkasan pembelian. } \\
\text { Pelaksanaan Ijab dan Qabul pada Hijup.com } \\
\text { dilakukan melalui perantara tulisan dan } \\
\text { tindakan digital. }\end{array}$ \\
\hline 2. & Kemanfaatan & $\begin{array}{l}\text { - Objek dan subjek } \\
\text { transaksi bermanfaat } \\
\text { secara fungsional. }\end{array}$ & $\begin{array}{l}\text { - Produk yang dijual bermanfaat langsung } \\
\text { bagi kemanusiaan, bukan produk najis, } \\
\text { atau produk yang diharamkan, yakni } \\
\text { pakaian Muslim dan Muslimah. } \\
\text { - Proses jual beli memberikan keuntungan } \\
\text { finansial tidak hanya kepada pengelola, } \\
\text { tetapi juga kepada desainer lokal yang } \\
\text { menjadi rekanan. } \\
\text { - Hijup.com bermanfaat sebagai media } \\
\text { sosialisasi brand lokal ke dunia } \\
\text { internasional. }\end{array}$ \\
\hline 3. & Keadilan & $\begin{array}{ll}\text { - } & \text { Keadilan kepada } \\
& \text { seluruh pembeli } \\
\text { - } & \text { Penetapan harga dan } \\
& \text { keuntungan secara } \\
& \text { wajar. } \\
\text { - } & \text { Tidak melakukan } \\
& \text { praktik monopoli }\end{array}$ & $\begin{array}{l}\text { - Tidak ada pembedaan, karena semua } \\
\text { dilakukan berdasarkan data digital. } \\
\text { - Harga lebih mahal dibanding e-commerce } \\
\text { lain, tetapi sebanding dengan kualitas } \\
\text { produk yang terjaga dengan baik. } \\
\text { - Tidak ada praktik monopoli perdagangan, } \\
\text { sebab ada kebijakan kerjasama dengan } \\
\text { produsen lokal untuk tumbuh bersama. }\end{array}$ \\
\hline 4. & Ketuhanan & $\begin{array}{l}\text { - Tidak melakukan } \\
\text { eksploitasi }\end{array}$ & $\begin{array}{l}\text { - Memberikan perlindungan data dan } \\
\text { informasi pengguna atau pelanggan. }\end{array}$ \\
\hline
\end{tabular}




\begin{tabular}{|c|c|c|c|}
\hline$\overline{\text { No }}$ & Prinsip & Indikator & Implementasi \\
\hline & & - Tidak melakukan riba & $\begin{array}{l}\text { - Secara langsung tidak ada riba, tetapi } \\
\text { proses pembayaran masih menggunakan } \\
\text { bank konvensional. }\end{array}$ \\
\hline 5. & Kejujuran & $\begin{array}{lr}\text { - Adanya } & \text { informasi } \\
\text { yang benar dan } \\
\text { lengkap r tentang } \\
\text { kualitas, harga, dan } \\
\text { waktu penyerahan } \\
\text { barang. } \\
\text { - } \begin{array}{l}\text { Tidak melakukan } \\
\text { penipuan. }\end{array}\end{array}$ & $\begin{array}{l}\text { - Informasi lengkap (warna, harga, sampai } \\
\text { bahan baku yang digunakan), termasuk } \\
\text { info tata cara perawatan. } \\
\text { - Waktu penyerahan jelas, karena yang } \\
\text { memilih jenis pengiriman adalah pembeli. } \\
\text { - Untuk menghindari penipuan transaksi, } \\
\text { Hijup.com menggunakan rekening atas } \\
\text { nama perusahaan, sehingga lebih aman. } \\
\text { - Untuk menghindari penipuan kualitas, } \\
\text { setiap produk yang masuk ke Hijup.com } \\
\text { harus melewati proses kuasi yang ketat. }\end{array}$ \\
\hline 6. & Kebebasan & - Adanya khiyar & $\begin{array}{l}\text { - Terdapat Khiyar majelis pada saat proses } \\
\text { di halaman "tas belanja" } \\
\text { - Terdapat Khiyar syarat dan Aib dengan } \\
\text { adanya ketentuan terur. }\end{array}$ \\
\hline 7. & $\begin{array}{l}\text { Akhlak/ } \\
\text { Etika }\end{array}$ & $\begin{array}{l}\text { - Melakukan kebaikan } \\
\text { dan menghindari } \\
\text { keburukan dalam } \\
\text { transaksi. }\end{array}$ & $\begin{array}{l}\text { - Penyampaian informasi secara benar dan } \\
\text { jujur. } \\
\text { - Tidak melakukan praktik riba (secara } \\
\text { langsung) } \\
\text { - Saling memberikan manfaat. }\end{array}$ \\
\hline 8. & Sahih & $\begin{array}{l}\text { Syarat rukunnya } \\
\text { terpenuhi: } \\
\text { a. Pihak yang berakad } \\
\text { (Penjual dan Pembeli) } \\
\text { - Mumayyiz } \\
\text { - Baligh } \\
\text { - Tanpa Paksaan } \\
\text { - Bukan orang yang } \\
\text { mubadhir }\end{array}$ & $\begin{array}{l}\text { Penjual } \\
\text { - Ketentuan Mumayyiz dan baligh ditandai } \\
\text { dengan adanya badan hukum PT yang } \\
\text { menaungi situs Hijup.com. } \\
\text { - Hijup.com tidak memiliki kuasa untuk } \\
\text { memaksa pembeli secara langsung. } \\
\text { - Hijup.com tidak dapat memaksa pembeli } \\
\text { untuk melakukan pembelian. Karena } \\
\text { keputusan untuk membeli produk } \\
\text { sepenuhnya ada di tangan pembeli. } \\
\text { - Hijup.com bukan orang sehingga kriteria } \\
\text { mubadhir sulit dilihat. } \\
\text { Pembeli } \\
\text { - Ketentuan Mumayyiz ditandai dengan } \\
\text { kemampuan pembeli mengikuti seluruh } \\
\text { proses dan alur pembelian. } \\
\text { - Ketentuan baligh ditandai dengan adanya } \\
\text { e-mail sebagai syarat menjadi pengguna. } \\
\text { - Ketentuan tanpa paksaan, terlihat pada } \\
\text { saat berada di halaman "tas belanja" di } \\
\text { mana pembeli memiliki kebebasan penuh } \\
\text { dalam transaksi. } \\
\text { - Ketentuan bukan orang yang mubadhir }\end{array}$ \\
\hline
\end{tabular}




\begin{tabular}{|c|c|c|}
\hline Prinsip & Indikator & Implementasi \\
\hline & 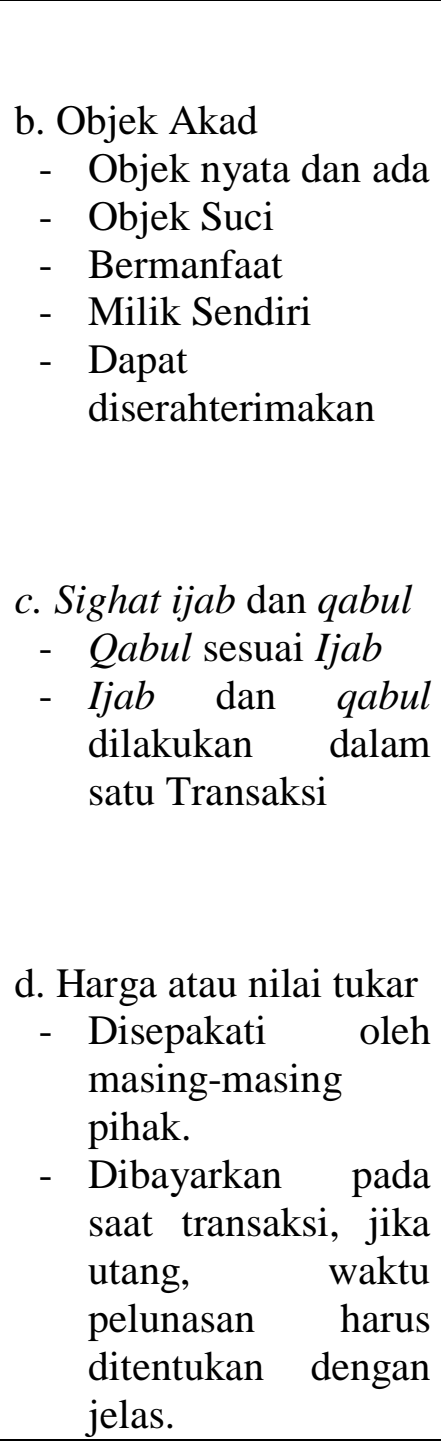 & $\begin{array}{l}\text { ditandai dengan ketiadaan produk mahal } \\
\text { yang menunjukkan gengsi seseorang. } \\
\text { - Objek jual beli ada dan tersedia, jika } \\
\text { sudah tidak ada, maka tertulis "Sold Out". } \\
\text { - Objek jual beli suci secara zat. Yaitu } \\
\text { perlengkapan Muslim dan Muslimah. } \\
\text { - Objek jual beli bermanfaat untuk } \\
\text { memenuhi kebutuhan sandang. } \\
\text { - Objek jual beli milik tenant dengan akad } \\
\text { wakalah. } \\
\text { - Objek nyata dan kasat mata, sehingga } \\
\text { dapat diserahterimakan. } \\
\text { - Pernyataan ijab dan qabul ada dalam } \\
\text { halaman "tas belanja" } \\
\text { - Pelaksanaan ijab dan qabul telah sesuai. } \\
\text { Informasi yang berikan penjual adalah } \\
\text { informasi yang sama dengan informasi } \\
\text { yang dikonfirmasi oleh pembeli. } \\
\text { - ijab dan qabul masih dalam satu transaksi } \\
\text { yang difasilitasi oleh "tas belanja" } \\
\text { - Harga ditetapkan oleh penjual, tidak ada } \\
\text { tawar-menawar, namun juga tidak ada } \\
\text { paksaan. } \\
\text { - Limitasi waktu pembayaran jelas, baik } \\
\text { transfer (1X12 jam) maupun COD. }\end{array}$ \\
\hline
\end{tabular}

\section{PENUTUP}

Berdasarkan uraian dan pembahasan telah dipaparkan sebelumnya, terdapat kesimpulan sebagai berikut:

Pertama, prinsip-prinsip jual beli dalam Islam secara spesifik terdiri atas prinsip kerelaan (ridhaiyyah), prinsip kemanfaatan atau kemaslahatan, prinsip keadilan, ketuhanan (tauhid), prinsip kejujuran, prinsip kebebasan, prinsip etika (akhlak), serta prinsip kebenaran (shahih).

Kedua, praktik transaksi jual beli yang terjadi pada e-commerce Hijup.com, telah menunjukkan adanya prinsip-prinsip jual beli dalam Islam yang terfasilitasi melalui berbagai kebijakan dan protokol pembelian di situs Hijup.com

Berdasarkan kesimpulan yang telah penulis uraian di atas, dalam rangka pengayaan dan pengembangan bisnis syariah, khususnya di bidang teknologi, digital, dan online, penulis berharap agar para pengelola e-commerce harus benar-benar memperhatikan prinsip-prinsip 
tersebut untuk kemudian dapat diterjemahkan dalam mekanisme transaksi pada situs $e$ commerce yang lebih baik dan terlihat.

\section{DAFTAR PUSTAKA}

Abdullah, R. (2011). Fikih muamalah. Bogor: Ghalia Indonesia.

As-Sabatin, Y. (2014). Bisnis Islami dan kritik atas praktik bisnis alas kapitalis. Bogor: alAzhar Press.

Azhar, A.B. (2000). Asas-asas hukum muamalat (hukum perdata Islam). Yogyakarta: UII Press.

Basaribu, C. dan Suhrawardi, K. L. (1996). Hukum perjanjian dalam Islam. Jakarta: Sinar Grafika.

Berita Satu. (2016). Konsumen Indonesia jadi korban penipuan online. Diakses dari http://www.beritasatu.com/iptek/367462-26-konsumen-indonesia-jadi-korbanpenipuan-online.html.

Bhinadi, A. (2018). Muamalah syar'iyyah hidup barokah. Yogyakarta: Depublish.

Dharma, A. (2016). Peran sains dan teknologi dalam percepatan pembangunan. Diakses dari http://agus_dh.staff.gunadarma.ac.id/Downloads/files/3699/Peran+Sains+\%26+ Teknologi+dlm+Percepatan+Pembangunan.pdf.

Dubai Technology Entrepreneur Centre (DTEC). (2017). Islamic economy. Diakses dari https://dtec.ae/islamic-economy.

Hadrawi, U. (2012). Tiga tanda baligh. Diakses dari http://www.nu.or.id/post/read/40361/tigatanda-baligh.

Hidayat, A.B. (1998). Studies in the Islamic law of contracts: The prohibition of gharar. Kuala Lumpur: International Law Book Service.

HIJUP.COM. Kebijakan umum. Diakses dari https://www.hijup.com/id/pages/policy.

HIJUP.COM. Panduan pabrik. Diakses dari https://www.hijup.com/id/pages/fabric_guide.

HIJUP.COM. Panduan ukuran. Diakses dari https://www.hijup.com/id/pages/size_guide.

HIJUP.COM. Retur dan pengembalian. Diakses dari https://www.hijup.com/id/pages/return_exchange.

Husaini, M. (2014). Bisnis e-commerce dalam perspektif Islam. Jurnal Ilmu Dakwah dan Pengembangan Komunitas, 9(2) 189.

Jawad, M.M. (2011). Fiqih lima mazhab: Ja'fari, Hanafi, Maliki, Syafi'i, Hambali, Terjemahan Masykur A.B. dkk. Jakarta: Lentera.

Karim, A. (2004). Bank Islam analisis fiqh dan keuangan. Jakarta: Raja Grafindo Persada.

Mardani. (2015). Hukum sistem ekonomi Islam. Jakarta: PT. Raja Grafindo Persada.

Medium. (2017). Malaysia new silicon valey for the global Islamic digital economy. Diakses dari https://medium.com/@GIEEC/malaysia-new-silicon-valley-for-the-global-islamicdigital-economy-d46a62991593. 
Munawir, A.W. (1997). Kamus al-Munawir: Arab-Indonesia terlengkap. Surabaya: Pustaka Progresif.

Mursal dan Suhadi. (2015). Implementasi prinsip Islam dalam aktivitas ekonomi: Alternatif mewujudkan keseimbangan hidup. Jurnal Penelitian. 9(1). 67-92.

Nurhayati, S. dan Wasilah. (2015). Akuntansi syariah di Indonesia. Edisi 4. Jakarta: Penerbit Salemba Empat.

Online24Jam.com. (2016). LDII luncurkan e-commerce syariah. Diakses dari http://online24jam.com/2016/11/08/18262/ldii-luncurkan-e-commerce-syariah/3/.

Qardhawi, Yusuf. (2004). Peran nilai dan moral dalam perekonomian islam. Terjemahan Didin Hafiduddin dkk. Jakarta: Robbani Press.

Qin, Z. (2009). Introduction to e-commerce. Beijing: Tsinghua University Press.

Rahman, A. G. (2010). Fiqih muamalat. Jakarta: Prenada Media Group.

Rasyid, Sulaiman. (1954). Fiqih Islam. Jakarta: Attahiriyah.

Rivai, V., Veithzal, A. P., Fawzi, M. G. H. (2011). Islamic transaction law in bussiness Dari teori ke praktik. Jakarta: Bumi Aksara.

Rivai, V. dan Bukhari, A. (2009). Islamic economic. Jakarta: Bumi Aksara.

Rozalinda. (2014). Ekonomi Islam teori dan aplikasinya pada aktivitas ekonomi. Jakarta: PT. Raja Grafindo Persada.

Sabiq, A. S. (1983). Fiqh as-sunnah. Beirut: Dar al-Fikr.

Safrudin, A. H. (2015). Transaksi e-commerce dalam perspektif hukum Islam dan kitab undang-undang hukum perdata. Jurnal el-Faqih, 1(1). 1-27.

Samad, M. (2016). Etika bisnis syariah: Berbisnis sesuai dengan moral Islam. Yogyakarta: Penerbit Sunrise.

Siddik, A.H. (1993). Inti dasar hukum dagang Islam. Jakarta: Balai Pustaka.

Sofyan, R. (2011). Bisnis syariah mengapa tidak? - Pengalaman penerapan pada bisnis hotel. Jakarta: Gramedia.

Sugiyono. (2009). Metode penelitian kuantitatif, kualitatif, dan $R \& D$. Bandung: Alfabeta.

Sukardi. (2008). Metodologi penelitian pendidikan kompetisi dan praktiknya. Jakarta: PT. Bumi Aksara.

Sulaiman, M. dan Zakaria, A. (2010). Jejak bisnis rasul. Jakarta: Penerbit Hikmah.

Syaltut, M. (1990). Tafsir al-qur'an al-karim. Jilid III, Terjemahan A. Dahlan, dkk. Bandung: CV. Diponegoro.

Tech In Asia Indonesia (2014). Tren StartUp di tahun 2016 mendatang. Diakses dari https://id.techinasia.com/talk/bagaimana-tren-startup-di-tahun-2016-mendatang.

World Bank. (2003) asymetric information. Diakses dari https://siteresources.worldbank. org/DEC/Resources/847971114437274304/Asymmetric_Info_Sep2003.pdf. 